\title{
Constraining political corruption: An empirical analysis of the impact of democracy*
}

\author{
Alessandro Pellegata \\ Department of Social and Political Studies, Università degli Studi di Milano (Italy) \\ Department of Social and Political Studies \\ Università degli Studi di Milano \\ Via Conservatorio 7 \\ 20122 Milano (Italy) \\ Tel. +390250321221 \\ Fax +390250321240 \\ alessandro.pellegata@unimi.it
}

Alessandro Pellegata is a post-doctoral fellow at the Department of Social and Political Studies, Università degli Studi di Milano (Italy).

Paper published in Democratization 20(7): 1195-1218.

Available

at:https://www.tandfonline.com/doi/abs/10.1080/13510347.2012.688031\#.UqGDneK

FdGM

\footnotetext{
* The original draft of this article was presented at the XXIII Annual Session of the Società Italiana di Scienza Politica; Roma, LUISS Guido Carli, 17-19 September 2009. I would like to thank Giovanni Carbone, Davide Grassi, and two anonymous referees for their precious help and suggestions on previous versions of the manuscript. This essay is part of the research project entitled 'The economic, social and political consequences of democratic reforms. A quantitative and qualitative comparative analysis', funded by a Starting Grant of the European Research Council (Grant no.262873, P.I. Giovanni Carbone).
} 


\section{Constraining political corruption: An empirical analysis of the impact of democracy}

The present article addresses the relationship between democracy and political corruption. Extending past studies, this article introduces important refinements that respond to theoretical and methodological concerns. The theoretical framework proposed here is developed based on an electoral conception of democracy, which makes it possible to avoid the potential endogeneity problems associated with substantial definitions of democracy. I argue that despite the influence of other important aspects of democracy, elections and inter-party competition per se help to constrain political corruption. The article examines two analytical dimensions of democracy, the current level of democracy and its degree of consolidation over time. Unlike previous studies, a cross-national empirical analysis of a sample of more than 100 countries reveals that when tested together, the level of democracy and its degree of longitudinal variation are both significantly related to the control of corruption. The level of democracy affects corruption in a nonlinear way. Hybrid regimes that are more autocratic than democratic show a lower level of corruption control than democracies, near-democracies, and closed dictatorships. The analysis also confirms that, despite having adopted different measures, more consolidated democracies are more powerful in constraining corruption.

Keywords: accountability; comparative analysis; competition; corruption; electoral conception of democracy.

In the last decade, with the publication of the Corruption Perception Index (CPI) by

Transparency International and the Control of Corruption Index (CC) by the World Bank, political science has placed increasing attention on political corruption. ${ }^{1}$ It has been found that corruption hinders economic growth, diminishes the quality of governance and decreases the level of trust that citizens place in political institutions. ${ }^{2}$ As a consequence, several scholars have conducted cross-sectional analyses of the potential determinants of political corruption. Most of these scholars have postulated that democracies, which hold governing officials more accountable to voters than do non-democracies, tend to present lower levels of corruption. ${ }^{3}$

However, all of these scholars have implicitly or explicitly adopted a substantial notion of democracy. This definition has implications for quantitative analyses of the consequences of democratization, such as corruption control. In fact substantial conceptions of democracy increase the potential endogeneity of 
democracy with several dependent variables, possibly invalidating the results of empirical analyses. ${ }^{4}$ Unlike past research, this study aims to assess the effects of the presence and the consolidation of democratic institutions on corruption control, relying on Schumpeter's conception of democracy as a system whose rulers are selected through competitive elections. ${ }^{5}$ The end goal of this study is to demonstrate that inter-party competition per se helps political systems to control corruption among elected officials. The proposed theoretical framework stems from the Public Choice school, which stresses the positive role of political and economic competition in constraining corruption. ${ }^{6}$ Consistent with the Schumpeterian tradition, electoral competition is understood as the primary source of accountability between representatives and voters. Democracies are expected to present lower levels of corruption because politicians are continuously under the threat of being removed from office. ${ }^{7}$ Therefore, the re-election imperative discourages politicians from engaging in corrupt practices.

This study analyses aspects of democracy that have previously been tested in other research- the current level of democracy and the degree of longitudinal variation- and advances two research hypotheses. ${ }^{8}$ The first hypothesis postulates that there exists a nonlinear relationship between the current level of democracy and corruption control, whereas the second states that more consolidated democracies are less corrupt. The results of a cross-sectional analysis conducted on a sample of more than 100 countries have confirmed both of the hypotheses. The most noteworthy empirical finding is one that previous studies have not been reported: simultaneously testing the two dimensions of democracy that are proposed in this article indicates that both are significantly related to the control of corruption. However, the current level of democracy begins to have a positive and significant impact on corruption control 
only after a certain threshold which indicates that democratic institutions are effectively able to generate a satisfactory mechanism of electoral control over representatives on behalf of their voters. Furthermore, the study shows that the relationship between the longitudinal variation in democracy and corruption control is significant irrespective of whether we measure democratic consolidation as the number of consecutive years a country has remained democratic, or by determining the overall democratic experience over time despite autocratic interruptions.

The present article is structured as follows. In the next section, the generic definition of political corruption that I have adopted is briefly defined. The third section presents a short review of the most important studies analysing the relationship between democracy and corruption. Successively, I discuss conceptual and methodological issues that past studies have not appropriately addressed, emphasizing the important refinements introduced in this article. In the fifth section, the theoretical framework guiding the analysis is explained, and two research hypotheses are advanced. The sixth section presents the data and variables used in the empirical analysis; the results of the analysis are discussed in the seventh section. Finally, in the last section, I present the main conclusions drawn from the empirical results and indicates their relevant implications for future research.

\section{Defining political corruption}

Political corruption is a complex phenomenon that is difficult to capture in a single definition. As noted by Andersson and Heywood, corruption can be defined only in generic terms because it encompasses a wide range of activities. ${ }^{9}$ There are many different types of corruption, that vary according to the sector in which they occur, the actors involved, their impact, and the degree to which they are formalized. A narrow 
definition, that is now standard in comparative political studies, essentially considers corruption as 'the misuse of public office for private financial gain'. ${ }^{10}$ This indicates that each type of corrupt activity tipically involves elected officials and/or appointed bureaucrats who abuse the power and authority with which they have been entrusted for private gain. Such activities take place at the expense of the collective community, thereby violating the norms that regulate the public office. ${ }^{11}$ Using the language adopted in principal-agent theory, we can consider political corruption to be a source of 'agency loss'. ${ }^{12}$ This term indicates the damage that is suffered by the principal (the citizen) because an agent (the public official) lacks the skill or incentive to complete the task delegated to her/him. Political corruption is a source of agency loss because when public agents are committed to deriving personal gain from their privileged positions, human, social, and economic resources are diverted from the public interest. When political corruption becomes an endemic phenomenon in a country, it pervades the highest levels of government, generally eroding confidence in good governance, the rule of law, and economic stability. Thus, corruption distorts the central functions of the government. ${ }^{13}$

\section{Background literature}

Several recent studies have analyzed the institutional determinants of political corruption. For instance, one group has explored whether the presence of democratic institutions helps to constrain corruption. ${ }^{14}$ Another group of studies has examined the effects of different political and institutional characteristics, including the unitary or federal nature of the state, the electoral system adopted, and the structure of competition. ${ }^{15}$ The theoretical argument underlying these studies is similar: as compared to autocracies, democracies are more effective in constraining corruption 
because of the accountability relationship that is established between politicians and voters through contested elections. Furthermore, democratic systems with political and institutional characteristics that facilitate the monitoring and sanctioning of elected officials by voters engender better control of political corruption.

Two recently published articles that belong to the group of studies described above have reported particularly interesting results concerning the relationship between democracy and corruption. Treisman conducted a cross-sectional analysis of a sample of 34-64 countries and tested the effects of political, institutional, economic, and cultural factors on the control of corruption. ${ }^{16} \mathrm{He}$ demonstrated that countries with Protestant tradition, a British colonial history, higher levels of economic development, and openness to international trade generally present lower levels of political corruption; federal states to be more corrupt. Examining the impact of democratic institutions and procedures on political corruption, Treisman analysed two aspects that had previously been tested by Sandholtz and Koetzle: the current level of democracy and the length of exposure to democracy. ${ }^{17}$ Like Sandholtz and Koetzle, Treisman failed to find empirical support for the impact of the level of democracy; however, he did show that more consolidated democracies generally displayed lower levels of corruption.

The second important article that is worth discussing is by Blake and Martin. These scholars essentially confirmed Treisman's results by performing an empirical analysis of a sample of 50-82 countries. ${ }^{18}$ They found that Protestant tradition, a British colonial heritage, economic development, and openness to international trade are negatively correlated with perceived political corruption, but they did not find significant results for federalism. In commenting on the effects of democracy, the two authors emphasized that it is not the current level of democracy that helps to control 
political corruption but rather the length of exposure to democratic institutions and practices.

\section{Conceptual and methodological issues in the study of the impact of democracy on corruption control}

Although the studies discussed above reported interesting results regarding the effects of democracy on corruption, I think that they failed to sufficiently account for important theoretical and methodological issues that, if considered, can refine our understanding of the relationship between these two phenomena.

The first issue is the notion of democracy adopted in past studies. All of the authors cited have adopted a substantial conception of democracy and have measured the current level of democracy using the Freedom House index or its Political Rights component. ${ }^{19}$ Blake and Martin have explicitly stated that electoral institutions are necessary but not sufficient conditions to define a political regime as democratic. ${ }^{20}$ Rather, they have emphasized the need to consider other factors that affect the 'vitality' of a democracy, including substantive authority for elected officials, freedom of political organization, realistic opportunities for the political opposition to gain power through elections, freedom from domination by governmental or private authorities and minority rights. ${ }^{21}$ Nevertheless, an indicator that reflects a substantial conceptualization of democracy can be seriously affected by endogeneity problems given the various dependent variables that can operationalize the potential consequences of the democratization process. Endogeneity risks invalidating the results and implications of an empirical analysis. For this reason, I have adopted an electoral notion of democracy and I have used only indicators that are consistent with such a conceptualization. As Carbone noted, this strategy is particularly appropriate in 
quantitative studies of the consequences of democratization, such as its effects on political corruption. ${ }^{22}$ This approach permits us to treat democracy as an explanatory factor, increases the set of potential phenomena that we can use to test the role of democratization, and accordingly helps us avoid most of the problems of endogeneity associated with dependent variables. ${ }^{23}$

A second problem that has hampered past studies is the erroneous conceptualization of the relationship between the current level of democracy and the degree of political corruption. This conceptualization may be why Blake and Martin, and previously, Goldsmith, Sandholtz and Koetzle and Treisman, did not find a significant correlation between these two variables. Each of these scholars expected an increase in the current level of democracy to be associated with the improved capacity of political systems to constrain corruption. However, theoretical arguments and empirical evidence have led me to hypothesize a nonlinear relationship between the level of democracy and control of corruption. As argued by Scott, democratization and corruption are linked. ${ }^{24}$ The process of democratization involves the separation of political elites, who are selected through electoral competition, from economic elites, who are increasingly independent from the political authority. The former maintains the power of coercion, whereas the latter manage a large share of the economic resources that were previously controlled by the political elite. In imperfect forms of democracy, this separation generates a political context dominated by confusion and uncertainty and encourages corrupt practices in which powerful public officials abuse their position to benefit particular interest groups in exchange for private financial gain. Montinola and Jackman, as well as Sung, have provided empirical support for this argument by demonstrating that unconsolidated democracies exhibit higher levels of political corruption than autocracies and consolidated democracies. ${ }^{25}$ Nevertheless, 
unlike those studies, the present article increases the robustness of the empirical results by controlling for the impact of the duration of democracy and several other variables that the literature has found to be significantly related to political corruption. $^{26}$

A third important innovation introduced in the present article is the strategy used to operationalize the consolidation of democratic regimes over time. Blake and Martin have considered democratic regimes to be consolidated if they present all of the characteristics associated with the political rights component of the Freedom House index for at least twenty years. ${ }^{27}$ However, in my opinion, it is problematic to establish thresholds in defining the length of time necessary for a democratic regime to become consolidated. Although these two scholars considered a period of twenty years to be a plausible threshold, such a parameter cannot be be justified by a valid theoretical argument. In contrast, this study prefers to operationalize democratic consolidation using continuous variables that measure the effective time exposure of different political regimes to democratic institutions and practises. This operationalization strategy is more flexible than Blake and Martin's and makes it possible to measure the degree of democratic consolidation according to two different indicators. One indicator measures the 'age' of the democratic regime, i.e. the number of years that it has been democratic, whereas the other tallies the total number of years that a political regime has been democratic even when those years have been punctuated by periods of autocracy. Blake and Martin contested the latter measure of democratic consolidation, which was previously adopted by Sandholtz and Koetzle, by drawing upon the examples of Argentina and Spain. According to this measure Argentina gained more democratic experience than Spain during the World War II period. ${ }^{28}$ Nevertheless, this measure has been perceived as misleading because 
whereas Spain had completed its twentieth consecutive year under democratic rule in 1996, Argentina had only reached its thirteenth consecutive year of democracy. ${ }^{29}$ However, the two authors did not consider the fact that familiarity with democratic practices before an authoritarian period can help political systems to constrain corruption because such familiarity facilitates the re-establishment of free and fair political competition and the rule of law. To capture this aspect of the consolidation of democratic regimes over time, this study, unlike Treisman's, not only examines the facts of the post World War II period but also captures long lived countries' exposure to democracy in the nineteenth century and the first half of the twentieth century. ${ }^{30}$ In Central and Eastern Europe, for instance, countries such as Czechoslovakia and Poland had experienced some forms of democracy before the socialist regimes were established, whereas others, such as Romania and Russia, never lived under democratic rule before the early 1990s.

\section{Theoretical framework and research hypotheses}

This study, employing an electoral conception of democracy, emphasizes the institutional roots of corruption. My research thus examines the incentives and restraints that democratic institutions provide for elected officials and business groups that might possibly engage in corrupt practises. The general theoretical argument states that electoral competition per se helps to constrain corruption because of the relationship of accountability between politicians and voters. In a democracy politicians have fewer incentives to extract private gains from bribes because they must periodically compete in elections and because their position is not guaranteed in the way that it is in non-democracies. Therefore, as noted by Rose-Ackerman, the imperative of re-election forces politicians to project an image of honesty and 
responsibility because voters can easily replace them. ${ }^{31}$ As Przeworski stated, consistent with the Schumpeterian tradition, the risk of politicians to be removed from office constitutes the substantial difference between democracies and autocracies. ${ }^{32}$ Furthermore, democratic institutions discourage corruptors from bribing members of the government. The possibility and practice of government alternation imply that politicians cannot always credibly promise that the particular laws and regulations that they adopt will remain in effect in the future. ${ }^{33}$ This fact raises the costs of corruption and encourages individuals and business groups to respect the rule of law. $^{34}$

Although it takes a different notion of democracy as its point of departure, this study identifies the same two analytical dimensions of the democratization process that have been noted in previous studies. ${ }^{35}$ The first dimension refers to the level of democracy. Different political regimes can be placed on a continuum according to the level of democracy of their institutions. This continuum ranges from non-democracies to consolidated democracies, with different types of political regimes associated with various levels of democracy. ${ }^{36}$ The first research hypothesis that I advance refers to this dimension.

$\mathrm{H}_{1}$ : A country's current level of democracy affects its capacity to constrain political corruption in a nonlinear manner.

More precisely, I hypothesize that this relationship is u-shaped. Figure 1, which depicts the distribution of the countries included in the sample according to their level of democracy and their degree of corruption control, seems to confirm this trend. My prediction is that "hybrid" regimes will present higher levels of corruption 
than will both dictatorships and consolidated democracies because of the weak electoral control mechanism that they employ. Numerous post-communist countries, particularly Russia, and Latin American states such as Argentina and Brazil provide substantial evidence in favour of this argument. In these countries, corruption increased after the introduction of elections and party competition and the substitution of a free-market economy for active state economic intervention. ${ }^{37}$ The pronounced corruption-constraining effects of democracy should emerge only when political competition begins to generate an accountability relationship between voters and politicians. However, hybrid regimes represent a 'gray zone' in which different combinations of democratic procedures and authoritarian practices are possible. ${ }^{38}$ It will be interesting to assess the point at which a unit increase in the level of democracy begins to play a positive role in constraining corruption.

Figure 1 about here

Nevertheless, as various scholars have argued, in assessing the consequences of democratization, one should not seek to determine immediate, proximal results but should rather focus on long-term, incremental effects generated by the evolution of institutional setting over time. ${ }^{39}$ Thus, the key distinction may not be between the levels of democracy of different political regimes but may instead be between those countries that have accumulated a certain degree of experience with democracy and those that have not. Therefore, this discussion introduces a second dimension of democratization: the longitudinal variation in democracy. ${ }^{40}$ This dimension can be used to assess the degree of consolidation of democratic regimes, quantifying their experience with democratic procedures and practices over time. The basic theoretical argument is that consolidated democracies are more likely to exhibit institutionalized 
mechanisms of electoral control that constrain corruption than are dictatorships, hybrid regimes, or unconsolidated democracies. Thus, the second research hypothesis is as follows:

$\mathrm{H}_{2}$ : Countries that have accumulated more democratic experience over time are less corrupt.

At first glance, the level of democracy and the degree of longitudinal variation seem to be conflicting aspects of the democratization process. In fact, however, as Carbone noted, they must be combined in a unique analytical framework. The presence of elections and inter-party competition is the basic requirement that must be met before we can investigate the possible consequences of democratization (procedural conception). Then, it is important to consider both the extent to which a country has been fully democratized (level) and the length of time for which it has been democratic (longitudinal variation). ${ }^{41}$

\section{Data and variables}

To test the validity of the research hypotheses above, I have employed the 'Democracy cross-national dataset' compiled by Pippa Norris, which collects data on social, economic, cultural, and political characteristics of 191 nations using over 1000 variables. $^{42}$

The dependent variable, perceived political corruption, has been operationalized using CC developed by the World Bank. This indicator ranges from 2.5 (more corruption) to +2.5 (less corruption) ${ }^{43} \mathrm{CC}$ is consistent with the generic definition of corruption presented earlier because it is a product of aggregated data 
obtained through various polls and surveys that capture somewhat different aspects of corruption. As noted by Kaufmann, Kraay, and Mastruzzi, CC includes activities that range from 'petty' corruption - 'additional payments to get things done' - to 'grand' corruption in the political arena or the tendency of economic elites and private interests to engage in 'state capture'. ${ }^{4}$

For the theoretical and methodological reasons explained above, I have operationalized the current level of democracy with the Polity IV index, which is based on a minimalist definition of democracy. ${ }^{45}$ The Polity conceptual scheme in fact consists of six component measures that record the key qualities of executive recruitment, constraints on executive authority, and political competition. ${ }^{46}$ This index includes a spectrum of different governing authorities on a 21-point scale ranging from 0 (hereditary monarchy) to 20 (consolidated democracy). ${ }^{47}$ To check the robustness of the results obtained via POLITY, I have also tested alternative indicators of the level of democracy using three different indexes: the Polyarchy Index developed by Vanhanen (VAN), the Contestation index by Coppedge, Alvarez, and Maldonado (CONT), and the Political Rights component of the Freedom House index (PR) ${ }^{48}$ These three indicators differ from POLITY and from one another in terms of the attributes chosen to measure the level of democracy and the aggregation rule used to generate the overall quantitative index. ${ }^{49}$ Given its nature, PR is inconsistent with the purpose of this study. However, I have decided to use it because PR has been the most commonly used indicator of the level of democracy in past studies. As previously mentioned, I have proposed two different proxies of the longitudinal variation in democracy. The first, called Age of Democracy (AGEDEM), which measures the number of consecutive years a country had remained democratic as of the year when the degree of political corruption is measured (2000). The second 
index is called Democratic Years (DEMYEARS) and is the sum of the overall number of years a country had remained democratic, despite interruptions, between 1800 (or the year of independence) and 2000. Both of these indicators have been based upon each country's POLITY score in every year under examination. As proposed by the researchers who worked on the PolityIV Project, a political regime is considered a democracy when it obtains a score between 16 and 20 on the Polity scale. ${ }^{50}$

The validity of the research hypotheses has been controlled by including several control variables in the analysis. These variables represent the economic, institutional, and cultural determinants of corruption that have already been tested by Treisman as well as Blake and Martin. Economic development is measured using the natural logarithm of the GDP per capita as of 2000 (logGDP), whereas openness to trade is measured using the amount of imports as a percentage of GDP in 2000 (IMPORTS). The necessary data are taken from the World Development Indicators. ${ }^{51}$ The degree of state intervention in the market is operationalized using the Index of Economic Freedom developed by the Fraser Institute (ECON_FREE). ${ }^{52}$ FED, PROTEST and BRITCOL are three dummy variables. The first takes a value of 1 for federal countries, the second for Protestant countries and the third for former British colonies.

Table 1 presents the descriptive statistics for all of the variables included in the analysis. The last column of the table displays the type of relationship hypothesized between the different explanatory factors and CC. A positive (negative) sign indicates a predicted positive (negative) relationship between the independent variable and the control of corruption, whereas the presence of both a positive and a negative sign indicates that the literature offers opposing theoretical arguments and 
contradictory empirical results. The expression 'nonlinear' means that I expect a nonlinear relationship between the level of democracy and corruption control.

Table 1 about here

\section{Empirical Results}

The main empirical analysis consists of six OLS regression models with robust standard errors to control for heteroschedasticity. The results are summarized in Table 2. The first three models test the effects of AGEDEM and the linear, quadratic, and cubic relationship between POLITY and CC in the year 2000, respectively. Models 4, 5, and 6 re-run the first three models but substitute AGEDEM with DEMYEARS. All of the models also include the six control variables described above and have been tested on a sample of 112 countries. ${ }^{53}$

Table 2 about here

The main results can be summarized as follows. Hypothesis 1, suggesting the presence of a nonlinear relationship between the level of democracy and the capacity of states to control political corruption, has been confirmed. Table 2 shows that POLITY and CC are significantly related only in a quadratic manner. In contrast, the linear and cubic relationships between the two variables are never statistically significant. The sign of the regressions coefficients associated with POLITY and POLITY ${ }^{2}$ indicates that, as hypothesized, there is a $\mathrm{u}$-shaped relationship between the current level of democracy and corruption control. Hybrid regimes with more autocratic than democratic elements tend to be more corrupt not only than consolidated democracies and those regimes with diminished forms of democracy but also than closed dictatorships. Only after a certain threshold (at a POLITY value 
around 16) does a unit increase in the level of democracy start to have a significant and positive impact on corruption control. ${ }^{54}$ Given that, as we have already seen, a political regime can be considered a democracy if it achieves a Polity score of at least 16 , this result indicates that democratic institutions help to constrain political corruption only when they become fully competitive. Moreover, unlike that of Montinola and Jackman and that of Sung, my analysis demonstrates that the significant marginal effect of the level of democracy on corruption control, as the first changes in a quadratic relationship, survives to the control for the effects of the longitudinal variation in democracy and other important explanatory factors (although its magnitude is relatively low). ${ }^{55}$

AGEDEM and DEMYEARS are found to be significantly and positively related to CC in all six models, which confirms Hypothesis 2. Regardless of the proxy used to operationalize the longitudinal variation in democracy, more consolidated democratic regimes generate a better capacity to control political corruption. Although the differences are minimal, with regard to the AIC values (Akaike Information Criterion), we conclude that the model that provides the best fit for the data distribution is Model 5. This model includes the first polynomial transformation of POLITY and DEMYEARS. Given the high level of correlation between the two indexes $(r=0.93)$, it was preferable to test AGEDEM and DEMYEARS independently. ${ }^{56}$ However, an attempt has been made to isolate the impact of the overall accumulated democratic experience, regardless of autocratic interruptions, from the effects associated with long-term democracy. I have also tested Model 5, excluding those countries that were democratic without interruption from 1945 to 2000 and that report both the highest levels of democracy and the highest levels of 
corruption control. ${ }^{57}$ With the sample thus reduced to 98 countries, DEMYEARS remains significant at the 0.05 level.

To increase the validity of the conclusions of the study, I checked the robustness of the findings obtained from the main empirical analysis across alternative measures of corruption control and democracy levels and for different time periods. ${ }^{58}$ Despite the lesser country coverage, substituting CC with CPI provided the same results as those presented in Table 2. Moreover, as we can see in Table 3, the significant effects of democracy on the control of corruption were also present in 1998, 2002, and 2003. ${ }^{59}$ Therefore, the two research hypotheses are valid for other recent years than 2000 .

Table 3 about here

Finally, Table 4 reports the results of the OLS regression models with which the alternative indicators of the level of democracy described above (CONT, VAN, and PR) have been tested. ${ }^{60}$ These results are particularly important because they reveal that the quadratic relationship between the current level of democracy and the control of corruption is also significant when indexes that are conceptually and methodologically different from POLITY are used.

Table 4 about here

Among the control variables tested, the level of economic development $(\log \mathrm{GDP})$, the degree of economic freedom (ECON_FREE), and the Protestant tradition (PROTESTANT) were always positively and significantly related to the control of corruption. As demonstrated by their regression coefficients, the effects of $\log$ GDP and ECON_FREE were generally the most relevant. Unlike in past studies, 
the impact of IMPORTS on CC was never significant. This finding is likely due partially to the fact that the openness of the market is captured by ECON_FREE and partially to the problem of endogeneity associated with the level of imports and corruption. ${ }^{61}$ As explained by Treisman, exposure to imports may reduce corruption, but corrupt officials are also stimulated to erect rent imposing barriers to international trade. ${ }^{62}$ Although the sign associated with the regression coefficient of FED is always positive, suggesting a potential beneficial effect of federalist institutions on corruption control, this variable has never been significant. Based on the previous literature, as shown in Table 1, this study has hypothesized both a corruption-enhancing and a corruption-constraining impact of federalism on corruption. ${ }^{63}$ Federal systems, in fact, may strengthen accountability (and reduce corruption) by distributing checks and balances among different levels of governments. However, an excessive concentration of power at the local level may weaken accountability (and increase corruption) in the central government. Therefore, it is plausible that these two effects may cancel one another out, thus producing no consequences regarding the control of corruption. This finding may also help to explain the contradictory results found in the literature. Finally, as explained by Treisman, a British colonial heritage influences the control of corruption both directly and via other cultural factors such as religious traditions and the legal system, the latter of which was not included in the analysis. ${ }^{64}$ This finding may most likely be a reason for the lack of significant effects of BRITCOL on CC, even though in some cases, its regression coefficients displayed a positive sign.

\section{Conclusions and Caveats}

This study assesses the effects of democracy on the capacity of states to control political corruption. The theoretical framework stems from Schumpeter's notion of 
democracy, which stresses the procedural aspect of inter-party competition and its role in making representatives accountable to citizens. In this study, I have examined two analytical dimensions -the level of democracy and its variation over time- and I have advanced two research hypotheses related to these dimensions. The first is that there exists a nonlinear relationship between the level of democracy and the control of corruption. The second postulates a positive effect of democratic consolidation, operationalized using two different indicators, on corruption control. The validity of these two hypotheses has been tested via a cross-national comparison using a large $\mathrm{N}$ sample of more than 100 countries. The empirical results that were obtained confirmed both of the hypotheses. These findings have several relevant implications for future research.

Although past studies showed that more substantial aspects of democracy are relevant in constraining corruption, this article demonstrates that the mere existence of contested elections and inter-party competition has a positive impact on corruption control. Nevertheless, democratic institutions play a corruption-constraining role only when they produce a satisfactory accountability relationship between politicians and voters. Only if the risk of removal from office is substantial will elected officials avoid corrupt practices. For this reason, hybrid regimes that exhibit a timid openness to electoral competition but remain intrinsically characterized by strong authoritarian elements present the highest levels of corruption, levels higher than those of closed dictatorships. The political instability and uncertainty typical of these regimes encourage politicians and public officials to abuse their privileged position, using it to obtain personal financial gain. Furthermore, the consolidation of democratic institutions and practices institutionalizes those mechanisms of electoral control that allow voters to monitor and punish corrupt public officials. This phenomenon occurs 
even if the process of consolidating a political regime's democratic institutions is interrupted by periods of authoritarian rule. A certain familiarity with democracy can help the regime to re-establish free and fair electoral competition and the rule of law.

Nevertheless, this study also poses several caveats to those scholars who analyze not only the relationship between democracy and corruption but also other general consequences that may accrue from democratization. First, the decision to adopt a specific notion of democracy and to use the corresponding indicators to operationalize its various dimensions is not a trivial one. Using an electoral conception of democracy allows scholars to isolate the role played by party competition from other aspects of democracy that surely play a relevant role in constraining corruption but can also increase the risk of endogeneity with the dependent variable. ${ }^{65}$ Second, future research should seek appropriate empirical strategies to address the problem of reciprocal causality associated with democracy and political corruption. The causal relationship between these two concepts may be the opposite of that proposed by this study. A higher capacity to constrain corruption among public officials can play a positive role in the process of democratic consolidation. One possible solution to this problem is to use the instrumental variables model, but the difficulty of identifying valid instruments renders this method less feasible. In conclusion, it is worth noting that an in-depth analysis of the role played by political institutions in different countries would help researchers to develop an understanding of the relationship between democracy and corruption. Among others, Kunicovà and Rose-Ackerman have demonstrated that specific electoral systems and forms of government are more successful than others in strengthening the accountability relationship between voters and elected officials, making it more politically costly for the latter to engage in corrupt activities. ${ }^{66}$ 


\section{Notes}

1. For more information on CPI, see www.transparency.org and Lambsdorff, 'Measuring Corruption'; regarding CC, see http://info.worldbank.org/governance/wgi/index.asp and Kaufmann, Kraay, and Mastruzzi, 'Measuring Governance'.

2. Mauro, 'Corruption and Growth'; Kaufmann, Kraay, and Mastruzzi, 'Measuring Governance'; Anderson and Tverdova, 'Corruption, Political Allegiances, and Attitudes'.

3. Goldsmith, 'Slapping the Grasping Hand'; Sandholtz and Koetzle, 'Accounting for Corruption'; Treisman 'The Causes of Corruption'; Blake and Martin, 'The Dynamics of Political Corruption'.

4. Carbone, 'The Consequences of Democratization'; Munck and Verkuilen, 'Conceptualizing and Measuring Democracy'.

5. Schumpeter, Capitalism, Socialism and Democracy.

6. Tullock, 'The Welfare Costs of Tariffs, Monopolies and Theft'; Krueger, 'The Political Economy of the Rent-seeking Society'; Rose-Ackerman, Corruption: A Study in Political Economy; Corruption and Government.

7. Przeworky, Democracy and the Market; 'Minimalist Conception of Democracy'.

8. Sandholtz and Koetzle, 'Accounting for Corruption'; Treisman, 'The Causes of Corruption'; Blake and Martin, 'The Dynamics of Political Corruption'.

9. Andersson and Heywood, 'The Politics of Perceptions'.

10. Kaufmann, Kraay, and Zoido-Lobaton, 'Governance Matters'; Rose-Ackerman, Corruption and Government; Sandholtz and Koetzle, 'Accounting for Corruption'; Treisman, 'The Causes of Corruption'; Kunicovà and Rose-Ackerman, 'Electoral Rules and Constitutional Structures'.

11. See Warren, 'What Does a Corruption Mean in a Democracy?'.

12. Lupia, 'Delegation and its Perils'; Strøm et al., 'Challenges to Parliamentary Democracies'.

13. Langseth, 'Measuring Corruption'.

14. Goldsmith, 'Slapping the Grasping Hand'; Sandholtz and Koetzle, 'Accounting for Corruption'; Treisman, 'The Causes of Corruption', Montinola and Jackman, 'Sources of Corruption'; Sung, 'Democracy and Political Corruption'; Blake and Martin, 'The Dynamics of Political Corruption'.

15. Rose-Ackerman, Corruption and Government; Perrson, Tabellini, and Trebbi, 'Electoral Rules and Corruption'; Gerring and Thacker, 'Political Institutions and Corruption'; Kunicovà and Rose-Ackerman, 'Electoral Rules and Constitutional Structures'; Tavits, 'Clarity of Responsibility and Corruption'; Nyblade and Reed, 'Who Cheats? Who Loots?'.

16. Treisman, 'The Causes of Corruption'.

17. Sandholtz and Koetzle, 'Accounting for Corruption'.

18. Blake and Martin, 'The Dynamics of Political Corruption'.

19. Goldsmith, 'Slapping the Grasping Hand'; Sandholtz and Koetzle, 'Accounting for Corruption'; Treisman, 'The Causes of Corruption' and Blake and Martin, 'The Dynamics of Political Corruption'.

20. Blake and Martin, 'The Dynamics of Political Corruption'.

21. Blake and Martin, 'The Dynamics of Political Corruption', 5. For a more complete discussion see the Political Rights checklist questions.

22. Carbone, 'The Consequences of Democratization'. A more appropriate way to solve the problems of endogeneity and reciprocal causality is to use the instrumental variables model. Nevertheless, as explained in the conclusion, the difficulty of 
identifying valid instruments makes the use of this method less feasible. See Stock and Watson, Introduction to Econometrics, Ch. 10.

23. By focusing on a procedural definition of democracy I examine one particular aspect of the relationship between democracy and corruption: the mechanism of electoral control exercised by the voters on the behaviour of representatives as introduced by partisan competition. This narrow focus inevitably limits the claims that I can make regarding the other potential corruption-constraining aspects of democracy as understood according to the substantial definitions. Nevertheless, stressing the procedural dimension of democracy permits me to empirically isolate and robustly analyze one of the potential causal mechanisms that links democracy and corruption.

24. Scott, Comparative Political Corruption.

25. Montinola and Jackman, 'Sources of Corruption'; Sung, 'Democracy and Political Corruption'.

26. Montinola and Jackman, 'Sources of Corruption'; Sung, 'Democracy and Political Corruption'. In note 7 of their article, Blake and Martin refer to these studies by stating that: 'It is unclear whether or not these studies' results would be robust to the inclusion of the other variables consistently confirmed in past research and discussed in our literature review (...). When we present our model here, we focus on the linear relationship discussed in other previous research; a polynomial transformation does not provide a significantly better fit in any of the five years under examination (19962000)'.

27. Blake and Martin, 'The Dynamics of Political Corruption', 4-5.

28. Sandholtz and Koetzle, Accounting for Corruption', 42.

29. Blake and Martin, 'The Dynamics of Political Corruption', 4.

30. Treisman, 'The Causes of Corruption', 413.

31. Rose-Ackerman, Corruption: A Study in Political Economy; Corruption and Government.

32. Schumpeter, Capitalism, Socialism and Democracy; Przeworski, Democracy and the Market; 'Minimalist Conception of Democracy'.

33. Montinola and Jackman, 'Sources of Corruption'.

34. Horowitz, Hoff and Milanovic, 'Government Turnovers'.

35. Sandholtz and Koetzle, Accounting for Corruption'; Treisman, 'The Causes of Corruption' and Blake and Martin, 'The Dynamics of Political Corruption'.

36. Elkins, 'Gradations of Democracy?'. Elkins conducted several empirical tests and found that graded measures of democracy have better validity and reliability than dichotomous indexes.

37. Varese, 'The Transition to the Market and Corruption'; Manzetti and Blake, 'Market Reforms and Corruption'; Montinola and Jackman, 'Sources of Corruption'.

38. For a discussion on the varieties of hybrid regimes see, among others, Diamond, 'Thinking About Hybrid Regimes'; Carothers, 'The End of Transition Paradigm'.

39. Muller, 'Democracy, Economic Development, and Income Inequality'; Gerring et al., 'Democracy and Economic Growth'; Carbone, 'Do All Things Go Together?; Carbone, 'The Consequences of Democratization'.

40. Muller, 'Democracy, Economic Development, and Income Inequality'.

41. Carbone, 'Do All Things Go Together?; Carbone, 'The Consequences of Democratization'.

42. See www.pippanorris.com. I made several personal additions to the original dataset.

43. I also conducted a robustness check running the empirical analysis while substituting for CC with CPI. Although these two indices are almost perfectly correlated ( $r=$ 0.97), I initially preferred to use CC because it covers a large number of countries; thus, its use increases the variation in the sample. Furthermore, as Kunicovà and Rose-Ackerman argued, CC is based on a more accurate methodology that expresses the observed data as a linear function of unobserved corruption plus a disturbance term that captures perception errors and sampling variation in the indicator. The model allows scholars to compute the variance of this disturbance term, which 
indicates the informativeness of the index. However, although the results obtained using CPI are not reported due to space limitations, they essentially confirm the results described in the text.

44. Kaufmann, Kraay and Mastruzzi, 'Measuring Governance'. For a discussion of the distinction between petty and grand corruption, see also Langseth, 'Measuring Corruption'.

45. See http://www.systemicpeace.org/polity/polity4.htm and Gurr, Jaggers, and Moore, 'The Transformation of Western State'.

46. The six component variables that form the aggregate Polity score are regulation of chief executive recruitment, competitiveness of executive recruitment, openness of executive recruitment, executive constraints, regulation of participation, and competitiveness of participation.

47. For the sake of simplicity, I have transformed the original Polity scale from -10 to +10 to a scale that ranges from 0 to 20 .

48. See Vanhanen, 'A New Dataset for Measuring Democracy', Coppedge, Alvarez and Maldonado, 'Two Persistent Dimensions of Democracy' and Gastil, Freedom in the World, respectively.

49. For a precise description of the differences among these alternative indexes, see Munck and Verkuilen, 'Conceptualizing and Measuring Democracy'. CONT is the most minimal measure of democracy; it relies on just one attribute of democracy contestation- which Coppedge, Alvarez, and Maldonado showed to be a fundamental dimension of all of the most important indicators of democracy. VAN relies on objective attributes of democracy: competition, measured using the percentage of votes gained by the largest party and participation, expressed in terms of voter turnout in the last elections. PR instead relies on more substantial attributes. Furthermore, these indexes differ according to the aggregation rule, which is additive for POLITY and PR, multiplicative for VAN and hierarchical (Guttman scale) for CONT.

50. The decision to establish a threshold after which a political regime is considered democratic can be contested. There is likely not to be a shared theoretical justification for this decision. Nevertheless, I prefer to generate my indicators of longitudinal variation in democracy based on a graded measure of democracy (POLITY) rather than from a dichotomous one, such as the ACLP index (see Alvarez et al., 'Classifying Political Regimes' and Przeworski et al., Democracy and Development). My decision to use POLITY is motivated by two factors. First, I prefer to use the same index for both of the analytical dimensions of democracy included. Second, using POLITY permits me to expand the period of time for which the political regimes are analyzed. The POLITY data, in fact, have been compiled since 1800 or the year of independence of each of the various countries, whereas the ACLP data have been recorded since 1946. This difference is particularly relevant when we test the effects of DEMYEARS because it permits me to take into account the experience with democracy accumulated even before the two World Wars and the establishment of autocratic regimes (especially socialist regimes) in several countries after 1945.

However, I have also run my models using the measures of AGEDEM and DEMYEARS based on the ACLP data for the period from 1946 to 2000. The results obtained using these indexes are the same as those obtained using the original indicators developed based on POLITY, and they exhibit the same level of significance.

51. See http://data.worldbank.org/indicator.

52. Unlike Treisman and Blake and Martin, I have not used the indicator developed by the Heritage Foundation (www.heritage.org) because of the issue of endogeneity with the dependent variable. This indicator contains an assessment of the perceived level of corruption in various countries.

53. In multivariate analyses, the original size of the sample $(\mathrm{N}=191)$ decreases because the PolityIV project measures the level of democracy only for countries with a population higher than 500,000 and because of missing values for different variables. 
54. This value is obtained by plotting the graph of the marginal effect of POLITY on CC as POLITY changes in a quadratic relationship. This graph is available upon request. For a more complete description of the procedure employed to compute the marginal effects of a variable given its quadratic relation, as well as a discussion of its fundamental importance vis-à-vis multiplicative interaction models, see also Brambor, Clarck and Golder, 'Understanding Interaction Models'.

55. Montinola and Jackman, 'Sources of Corruption'; Sung, 'Democracy and Political Corruption'.

56. The value of the Variance Inflation Factor (VIF) of a model that contains both AGEDEM and DEMYEARS indicates that, according to the accepted standards, the proportion of variance of DEMYEARS that is dependent on AGEDEM is particularly high, signalling a potential challenge to the robustness of the model.

57. These includes countries such as Australia, Canada, New Zealand, the United Kingdom, the United States, and northern continental European countries.

58. For a discussion of the importance of robustness checks in quantitative empirical analysis, see Casper and Tufis, 'Correlation Versus Interchangeability'.

59. The years tested are not contiguous because the $\mathrm{CC}$ data have been collected every two years from 1996 to 2002 and annually since 2003.

60. For ease of presentation in Table 4, I have presented only the tests for the quadratic relationship between the different indicators of the level of democracy and CC. This relationship, unlike the linear and cubic ones, is always significant for the three alternative indexes tested.

61. One of the five dimensions of ECON_FREE is the 'freedom to trade internationally'. See www.freetheworld.com.

62. Treisman, 'The Causes of Corruption'. The contradictory effects stressed by Treisman are reflected in the low regression coefficients obtained in his empirical analysis.

63. For the first type of hypothesis, see Treisman, 'The Causes of Corruption' and Gerring and Thacker, 'Political Institutions and Corruption'. For the second type, see Fisman and Gatti, 'Decentralization and Corruption' and Strøm et al., 'Challenges to Parliamentary Democracies'.

64. Treisman, 'The Causes of Corruption'.

65. Carbone, 'The Consequences of Democratization'; Munck and Verkuilen, 'Conceptualizing and Measuring Democracy'.

66. Kunicovà and Rose-Ackerman, 'Electoral Rules and Constitutional Structures'.

\section{Bibliographic references}

Alvarez, Mike, José Antonio Cheibub, Fernando Limongi, and Adam Przeworski. 'Classifying Political Regimes', Studies in Comparative International Development 31, no. 2 (1996): 3-36.

Anderson, Christopher J. and Yulia V. Tverdova. 'Corruption, Political Allegiances and Attitudes toward Government in Contemporary Democracies', American Journal of Political Science 47, no. 1 (2003): 91-109.

Andersson, Staffan, and Paul M. Heywood. 'The Politics of Perception: Use and Abuse of Transparency International's Approach to Measuring Corruption', Political Studies 57, no. 4 (2009): 746-67.

Blake, Charles H, and Christopher G. Martin. 'The Dynamics of Political Corruption: Re-examining the Influence of Democracy', Democratization 13, no. 1 (2006): $1-14$. 
Brambor, Thomas, William Roberts Clarck, and Matt Golder. 'Understanding Interaction Models: Improving Empirical Analyses', Political Analysis 14, no. 1 (2006): 63-82.

Carbone, Giovanni M. 'Do All Good Things go Together? Exploring the Political, Economic and Social Consequences of Democratization'. Paper presented at the 66th Annual National Conference of the Midwest Political Science Association (MPSA), Chicago, IL, April 3-6, 2008.

Carbone, Giovanni M. 'The Consequences of Democratization', Journal of Democracy 20, no. 2 (2009): 123-37.

Carothers, Thomas. 'The End of the Transition Paradigm', Journal of Democracy 13, no. 1 (2002): 5-21.

Casper, Gretchen, and Claudiu Tufis. 'Correlation Versus Interchangeability: The Limited Robustness of Empirical Findings on Democracy Using Highly Correlated Data Sets', Political Analysis 11, no. 2 (2003): 196-203.

Coppedge, Michael, Angel Alvarez, and Claudia Maldonado. 'Two Persistent Dimensions of Democracy: Contestation and Inclusiveness', The Journal of Politics 70, no. 3 (2008): 632-47.

Diamond, Larry. 'Thinking about Hybrid Regimes', Journal of Democracy 13, no. 2 (2002): 21-35.

Elkins, Zachary. 'Gradations of Democracy? Empirical Tests of Alternative Conceptualizations', American Journal of Political Science 44, no. 2 (2000): 287-94.

Fisman, Raymond, and Roberta Gatti. 'Decentralization and Corruption: Evidence Across Countries', Journal of Public Economics 83, no. 3 (2002): 325-45.

Gastil, Robert D. Freedom in the World: Political Rights and Civil Liberties. Westport, CT: Greenwood Press, 1985.

Gerring, John, Philip Bond, William Barndt and Carola Moreno. 'Democracy and Economic Growth: A Historical Perspective', World Politics 57, no. 3 (2005): 323-64.

Gerring, John, and Strom C. Thacker. 'Political Institutions and Corruption: The Role of Unitarism and Parliamentarism', British Journal of Political Science 34, no. 2 (2004): 295-330.

Goldsmith, Arthur A. 'Slapping the Grasping Hand: Correlates of Political Corruption in Emerging Markets', American Journal of Economics and Sociology 58, no. 4 (1999): 865-83.

Gurr, Tedd D, Keith Jaggers, and Will H. Moore. 'The Transformation of Western State: The Growth of Democracy, Autocracy, and State Power since 1800', Studies in Comparative International Development 25, no. 1 (1991): 73-108.

Horowitz, Shale, Karla Hoff, and Branko Milanovic. 'Government Turnover: Concepts, Measures and Applications', European Journal of Political Research 48, no. 1 (2009): 107-29.

Kaufmann, Daniel, Aart Kraay, and Pablo Zoido-Lobaton. 'Governance Matters'. World Bank policy research working paper n. 2196, The World Bank, Washington DC, 1999.

Kaufmann, Daniel, Aart Kraay, and Massimo Mastruzzi. 'Measuring Governance Using Cross-country Perceptions Data'. In International Handbook on the Economics of Corruption, ed. Susan Rose-Ackerman, 52-104. Northampton, MA: Edward Elgar Publishing, 2006.

Krueger, Anne O. 'The Political Economy of the Rent-seeking Society', American Economic Review 64 (1974): 291-303. 
Kunicovà, Jana, and Susan Rose-Ackerman. 'Electoral Rules and Constitutional Structures as Constraints on Corruption', British Journal of Political Science 35, no. 4 (2005): 573-606.

Lambsdorff, Johan G. 'Measuring Corruption: The Validity and Precision of Subjective Indicators.' In Measuring Corruption, eds. Charles Sampford, Arthur Shacklock, Carmel Connors and Fredrik Galtung, 81-100. Burlington, VT: Ashgate, 2006.

Langseth, Petter. 'Measuring Corruption'. In Measuring Corruption, eds. Charles Sampford, Arthur Shacklock, Carmel Connors and Fredrik Galtung, 7-44. Burlington, VT: Ashgate, 2006.

Lupia, Arthur. 'Delegation and Its Perils'. In Delegation and Accountability in Parliamentary Democracies, eds. Kaare Strøm, Wolfgang C. Müller and Torbjorn Bergman, 33-54. Oxford, New York: Oxford University Press, 2003.

Manzetti, Luigi, and Charles Blake. 'Market Reforms and Corruption in Latin America', Review of International Political Economy 3 (1996): 671-82.

Mauro, Paolo. 'Corruption and Growth', Quarterly Journal of Economics 110, no. 3 (1995): 681-712.

Montinola, Gabriella R, and Robert W. Jackman. 'Sources of Corruption: A Crosscountry Study', British Journal of Political Science 32, no.1 (2002): 147-70.

Muller, Edward N. 'Democracy, Economic Development, and Income Inequality', American Sociological Review 53, no. 1 (1988): 50-68.

Munck, Gerardo L, and Jay Verkuilen. 'Conceptualizing and Measuring Democracy: Evaluating Alternative Indices', Comparative Political Studies 35, no. 1 (2002): 5-34.

Norris, Pippa. Democracy Cross-national Dataset, 2008. http://www.pippanorris.com (accessed September 2010).

Nyblade, Benjamin, and Steven R. Reed. 'Who Cheats? Who Loots? Political Competition and Corruption in Japan, 1947-1993', American Journal of Political Science 52, no. 4 (2008): 926-41.

Persson, Torsten, Guido Tabellini, and Francesco Trebbi. 'Electoral Rules and Corruption', Journal of the European Economic Association 1, no. 4 (2003): 958-89.

Przeworski, Adam. Democracy and the Market. Cambridge, UK: Cambridge University Press, 1991.

Przeworski, Adam. 'Minimalist Conception of Democracy: A Defence'. In Democracy's Value, eds. Ian Shapiro, and Casiano Hacker Cordon, 23-55. Cambridge, UK: Cambridge University Press, 1999.

Przeworski, Adam, Mike E. Alvarez, José Antonio Cheibub, and Fernando Limongi. Democracy and Development: Political Institutions and Well-being in the World, 1950-1990. Cambridge, UK: Cambridge University Press, 2000.

Rose-Ackerman, Susan. Corruption: A Study in Political Economy. New York, NY: Academic Press, 1978.

Rose-Ackerman, Susan. Corruption and Government. Causes, Consequences and Reforms. Cambridge, UK: Cambridge University Press, 1999.

Sandholtz, Wayne, and William Koetzle. 'Accounting for Corruption: Economic Structure, Democracy, and Trade', International Studies Quarterly 44, no. 1 (2000): 31-50.

Schumpeter, Joseph A. Capitalism, Socialism and Democracy. New York, NY: Harper \& Brothers, 1942. 
Scott, James. Comparative Political Corruption. Englewood Cliffs, NJ: Prentice-Hall, 1972.

Stock, James H, and Mark W. Watson. Introduction to Econometrics. Boston, MA: Addison-Wesley Series in Economics, 2003.

Strøm, Kaare, Wolfgang C. Müller, and Torbjorn Bergman. 'Challenges to Parliamentary Democracies'. In Delegation and Accountability in Parliamentary Democracies, eds. Kaare Strøm, Wolfgang C. Müller and Torbjorn Bergman, 707-50. Oxford, New York: Oxford University Press, 2003.

Sung, Hung-En. 'Democracy and Political Corruption: A Cross-national Comparison', Crime, Law and Social Change 41, no. 2 (2004): 179-93.

Tavits, Margit. 'Clarity of Responsibility and Corruption', American Journal of Political Science 51, no. 1 (2007): 218-29.

Treisman, Daniel. 'The Causes of Corruption: A Cross-national Study', Journal of Public Economics 76, no. 3 (2000): 399-458.

Tullock, Gordon. 'The Welfare Costs of Tariffs, Monopolies and Theft', Western Economic Journal 5 (1967): 224-32.

Vanhanen, Tatu. 'A New Dataset for Measuring Democracy, 1810-1998', Journal of Peace Research 3, no. 2 (2000): 251-65.

Varese, Federico. 'The Transition to the Market and Corruption in Post-socialist Russia', Political Studies 45, no. 3 (1997): 579-96.

Warren, Mark E. 'What Does Corruption Mean in a Democracy?', American Journal of Political Science 48, no. 2 (2004): 328-43. 
Table 1. Descriptive statistics of the variables included in the analysis (year 2000).

\begin{tabular}{lcccccc}
\hline \multicolumn{1}{c}{ Variable } & Obs. & Mean & St. Dev. & Min & Max & Expectation \\
\hline CC & 186 & -0.039 & 1.004 & -1.927 & 2.337 & Dependent \\
CPI & 89 & 4.725 & 2.394 & 1.2 & 10 & Dependent \\
POLITY & 157 & 12.955 & 6.598 & 0 & 20 & nonlinear \\
VAN & 184 & 15.077 & 12.372 & 0 & 47.76 & nonlinear \\
CONT & 191 & 0.525 & 0.931 & -1.364 & 1.843 & nonlinear \\
PR & 191 & 3.418 & 2.243 & 1 & 7 & nonlinear \\
AGEDEM & 160 & 15.437 & 30.883 & 0 & 191 & + \\
DEMYEARS & 160 & 20.45 & 34.868 & 0 & 191 & + \\
logGDP & 185 & 7.631 & 1.617 & 4.439 & 11.323 & + \\
ECON_FREE & 122 & 6.371 & 1.054 & 3.413 & 8.565 & + \\
IMPORTS & 174 & 45.713 & 22.768 & 0.589 & 128.99 & + \\
FED & 191 & 0.727 & 0.446 & 0 & 1 & $+/-$ \\
PROTESTANT & 191 & 0.240 & 0.428 & 0 & 1 & + \\
BRITCOL & 191 & 0.329 & 0.471 & 0 & 1 & + \\
\hline
\end{tabular}


Table 2. OLS regression coefficients (with robust standard errors in parentheses) of CC (year 2000) on democracy indexes and alternative explanatory factors.

\begin{tabular}{|c|c|c|c|c|c|c|}
\hline & Model 1 & Model 2 & Model 3 & Model 4 & Model 5 & Model 6 \\
\hline POLITY & $\begin{array}{c}0.0023 \\
(0.0080)\end{array}$ & $\begin{array}{c}-0.1048^{* *} \\
(0.0484)\end{array}$ & $\begin{array}{c}0.0537 \\
(0.1037)\end{array}$ & $\begin{array}{c}-0.0007 \\
(0.0080)\end{array}$ & $\begin{array}{c}-0.1143 * * \\
(0.0466)\end{array}$ & $\begin{array}{c}0.0123 \\
(0.1025)\end{array}$ \\
\hline POLITY $^{2}$ & & $\begin{array}{c}0.0048 * * \\
(0.0022)\end{array}$ & $\begin{array}{l}-0.0114 \\
(0.0099)\end{array}$ & & $\begin{array}{c}0.0050 * * \\
(0.0021)\end{array}$ & $\begin{array}{c}-0.0078 \\
(0.0098)\end{array}$ \\
\hline POLITY $^{3}$ & & & $\begin{array}{c}0.0004 \\
(0.0002)\end{array}$ & & & $\begin{array}{c}0.0003 \\
(0.0002)\end{array}$ \\
\hline AGEDEM & $\begin{array}{c}0.0057 * * * \\
(0.0020)\end{array}$ & $\begin{array}{c}0.0053^{* * * *} \\
(0.0019)\end{array}$ & $\begin{array}{c}0.0045^{* * *} \\
(0.0019)\end{array}$ & & & \\
\hline DEMYEARS & & & & $\begin{array}{c}0.0064 * * * \\
(0.0017)\end{array}$ & $\begin{array}{c}0.0062^{* * *} * \\
(0.0017)\end{array}$ & $\begin{array}{c}0.0056 * * * \\
(0.0017)\end{array}$ \\
\hline $\log$ GDP & $\begin{array}{c}0.3553 * * * \\
(0.0389)\end{array}$ & $\begin{array}{c}0.3002 * * * \\
(0.0498)\end{array}$ & $\begin{array}{c}0.2990 * * * \\
(0.0516)\end{array}$ & $\begin{array}{c}0.3342 * * * \\
(0.0385)\end{array}$ & $\begin{array}{c}0.2754 * * * \\
(0.0480)\end{array}$ & $\begin{array}{c}0.2767 * * * \\
(0.0495)\end{array}$ \\
\hline ECON_FREE & $\begin{array}{c}0.2252 * * * * \\
(0.0693)\end{array}$ & $\begin{array}{c}0.2162 * * * \\
(0.0659)\end{array}$ & $\begin{array}{c}0.226 * * * \\
(0.0679)\end{array}$ & $\begin{array}{c}0.2192 * * * \\
(0.0674)\end{array}$ & $\begin{array}{c}0.2068 * * * \\
(0.0642)\end{array}$ & $\begin{array}{c}0.2116 * * * \\
(0.0661)\end{array}$ \\
\hline IMPORTS & $\begin{array}{c}0.0022 \\
(0.0020)\end{array}$ & $\begin{array}{c}0.0025 \\
(0.0021)\end{array}$ & $\begin{array}{c}0.0025 \\
(0.0021)\end{array}$ & $\begin{array}{c}0.0021 \\
(0.0019)\end{array}$ & $\begin{array}{c}0.0025 \\
(0.0020)\end{array}$ & $\begin{array}{c}0.0026 \\
(0.0020)\end{array}$ \\
\hline FED & $\begin{array}{c}0.0484 \\
(0.0976)\end{array}$ & $\begin{array}{c}0.0373 \\
(0.0995)\end{array}$ & $\begin{array}{c}0.0252 \\
(0.1012)\end{array}$ & $\begin{array}{c}0.0477 \\
(0.0950)\end{array}$ & $\begin{array}{c}0.0375 \\
(0.0967)\end{array}$ & $\begin{array}{c}0.0284 \\
(0.0984)\end{array}$ \\
\hline PROTESTANT & $\begin{array}{l}0.1907^{*} \\
(0.0996)\end{array}$ & $\begin{array}{c}0.2204 * * \\
(0.1046)\end{array}$ & $\begin{array}{l}0.2054^{*} \\
(0.1077)\end{array}$ & $\begin{array}{l}0.1830^{*} \\
(0.0971)\end{array}$ & $\begin{array}{c}0.2119 * * \\
(0.1020)\end{array}$ & $\begin{array}{l}0.1998^{*} \\
(0.1048)\end{array}$ \\
\hline BRITCOL & $\begin{array}{c}0.0318 \\
(0.0919)\end{array}$ & $\begin{array}{c}0.0363 \\
(0.0913)\end{array}$ & $\begin{array}{c}0.0306 \\
(0.0962)\end{array}$ & $\begin{array}{c}0.0437 \\
(0.0897)\end{array}$ & $\begin{array}{c}0.0450 \\
(0.0883)\end{array}$ & $\begin{array}{c}0.0385 \\
(0.0927)\end{array}$ \\
\hline Costant & $\begin{array}{c}-4.4240 * * * \\
(0.3643)\end{array}$ & $\begin{array}{c}-3.5723 * * * \\
(0.5771)\end{array}$ & $\begin{array}{c}-3.9609 * * * \\
(0.6185)\end{array}$ & $\begin{array}{c}-4.2303 * * * \\
(0.3588)\end{array}$ & $\begin{array}{c}-3.309 * * * \\
(0.5431)\end{array}$ & $\begin{array}{c}-3.635 * * * \\
(0.6165)\end{array}$ \\
\hline $\mathrm{R}^{2}$ & 0.8305 & 0.8369 & 0.8406 & 0.8388 & 0.8460 & 0.8483 \\
\hline AIC & 141.75 & 139.43 & 138.87 & 136.17 & 133.03 & 133.36 \\
\hline $\mathrm{N}$ & 112 & 112 & 112 & 112 & 112 & 112 \\
\hline
\end{tabular}

* Significant at 0.1

** Significant at 0.05 level.

*** Significant at 0.01 level. 
Table 3. OLS regression coefficients (with robust standard errors in parentheses) of CC in 1998, 2002 and 2003 on democracy indexes and alternative explanatory factors.

\begin{tabular}{|c|c|c|c|c|c|c|}
\hline & CC1998 & CC1998 & CC2002 & CC2002 & CC2003 & CC2003 \\
\hline POLITY & $\begin{array}{c}-0.0979 * * \\
(0.0432)\end{array}$ & $\begin{array}{c}-0.1010 * * \\
(0.0480)\end{array}$ & $\begin{array}{c}-0.1987 * * * \\
(0.0736)\end{array}$ & $\begin{array}{c}-0.2065^{* * *} * \\
(0.0706)\end{array}$ & $\begin{array}{c}-0.1209 * * \\
(0.0546)\end{array}$ & $\begin{array}{c}-0.1280 * * \\
(0.0509)\end{array}$ \\
\hline POLITY $^{2}$ & $\begin{array}{c}0.0043 * * \\
(0.0020)\end{array}$ & $\begin{array}{c}0.0043^{* *} \\
(0.0019)\end{array}$ & $\begin{array}{c}0.0080 * * \\
(0.0033)\end{array}$ & $\begin{array}{c}0.0082 * * \\
(0.0031)\end{array}$ & $\begin{array}{c}0.0049 * * \\
(0.0024)\end{array}$ & $\begin{array}{c}0.0050 * * \\
(0.0023)\end{array}$ \\
\hline AGEDEM & $\begin{array}{c}0.0054 * * \\
(0.0023)\end{array}$ & & $\begin{array}{c}0.0056 * * * \\
(0.0019)\end{array}$ & & $\begin{array}{c}0.0060 * * * \\
(0.0020)\end{array}$ & \\
\hline DEMYEARS & & $\begin{array}{c}0.0064 * * * \\
(0.0020)\end{array}$ & & $\begin{array}{c}0.0066 * * * \\
(0.0016)\end{array}$ & & $\begin{array}{c}0.0071 * * * \\
(0.0016)\end{array}$ \\
\hline $\log$ GDP & $\begin{array}{c}1.1372 * * * \\
(0.1517)\end{array}$ & $\begin{array}{c}1.0615^{* * * *} \\
(0.1458)\end{array}$ & $\begin{array}{c}0.3593 * * * \\
(0.0819)\end{array}$ & $\begin{array}{c}0.3218 * * * \\
(0.0806)\end{array}$ & $\begin{array}{c}0.3031 * * * \\
(0.0568)\end{array}$ & $\begin{array}{c}0.2752 * * * \\
(0.0549)\end{array}$ \\
\hline ECON_FREE & $\begin{array}{c}0.1291 * * * \\
(0.0465)\end{array}$ & $\begin{array}{c}0.1192 * * * \\
(0.0452)\end{array}$ & $\begin{array}{c}0.3614 * * * \\
(0.0712)\end{array}$ & $\begin{array}{c}0.3440 * * * \\
(0.0708)\end{array}$ & $\begin{array}{c}0.4230 * * * \\
(0.0681)\end{array}$ & $\begin{array}{c}0.4056 * * * \\
(0.0661)\end{array}$ \\
\hline IMPORTS & $\begin{array}{l}-0.0009 \\
(0.0023)\end{array}$ & $\begin{array}{c}-0.0005 \\
(0.0022)\end{array}$ & $\begin{array}{c}0.0023 \\
(0.0023)\end{array}$ & $\begin{array}{c}0.0025 \\
(0.0022)\end{array}$ & $\begin{array}{l}-0.0006 \\
(0.0020)\end{array}$ & $\begin{array}{c}0.0498 \\
(0.0912)\end{array}$ \\
\hline FED & $\begin{array}{c}0.0607 \\
(0.1144)\end{array}$ & $\begin{array}{c}0.0574 \\
(0.1111)\end{array}$ & $\begin{array}{c}0.0288 \\
(0.1152)\end{array}$ & $\begin{array}{c}0.0289 \\
(0.1105)\end{array}$ & $\begin{array}{c}0.0480 \\
(0.0967)\end{array}$ & $\begin{array}{c}0.1874 \\
(0.0952)\end{array}$ \\
\hline PROTESTANT & $\begin{array}{c}0.2674 * * \\
(0.1104)\end{array}$ & $\begin{array}{c}0.2511^{* *} \\
(0.1074)\end{array}$ & $\begin{array}{l}0.2225^{*} \\
(0.1143)\end{array}$ & $\begin{array}{l}0.2189 * \\
(0.1092)\end{array}$ & $\begin{array}{l}0.1992 * \\
(0.1014)\end{array}$ & $\begin{array}{l}0.1874 * \\
(0.0952)\end{array}$ \\
\hline BRITCOL & $\begin{array}{c}0.1760 \\
(0.0949)\end{array}$ & $\begin{array}{c}0.1891 \\
(0.0915)\end{array}$ & $\begin{array}{l}-0.0063 \\
(0.0961)\end{array}$ & $\begin{array}{c}0.0024 \\
(0.0918)\end{array}$ & $\begin{array}{l}-0.0345 \\
(0.0953)\end{array}$ & $\begin{array}{l}-0.0198 \\
(0.0916)\end{array}$ \\
\hline Costant & $\begin{array}{c}-4.8650 * * * \\
(0.6359)\end{array}$ & $\begin{array}{c}-4.5459 * * * \\
(0.6292)\end{array}$ & $\begin{array}{c}-4.6571 * * * \\
(1.0144)\end{array}$ & $\begin{array}{c}-4.2489 * * * \\
(1.0037)\end{array}$ & $\begin{array}{c}-4.861 * * * \\
(0.6997)\end{array}$ & $\begin{array}{c}-4.523 * * * \\
(0.6691)\end{array}$ \\
\hline $\mathrm{R}^{2}$ & 0.8071 & 0.8164 & 0.8292 & 0.8391 & 0.8344 & 0.8476 \\
\hline $\mathrm{AIC}$ & 152.81 & 147.52 & 140.85 & 134.78 & 138.74 & 129.53 \\
\hline $\mathrm{N}$ & 107 & 107 & 101 & 101 & 111 & 111 \\
\hline
\end{tabular}

* Significant at 0.1

** Significant at 0.05 level.

*** Significant at 0.01 level. 
Table 4. OLS regression coefficients (with robust standard errors in parentheses) of CC on alternative democracy indexes (CONT, VAN, PR).

\begin{tabular}{|c|c|c|c|c|c|c|}
\hline & CC2000 & CC2000 & CC2000 & CC2000 & CC2000 & CC2000 \\
\hline CONT & $\begin{array}{c}-0.1522^{* * *} \\
(0.0610)\end{array}$ & $\begin{array}{c}-0.1601 * * * \\
(0.0605)\end{array}$ & & & & \\
\hline $\mathrm{CONT}^{2}$ & $\begin{array}{c}0.2934 * * * \\
(0.0705)\end{array}$ & $\begin{array}{c}0.2738 * * * \\
(0.0677)\end{array}$ & & & & \\
\hline VAN & & & $\begin{array}{c}-0.0249 * * * \\
(0.0108)\end{array}$ & $\begin{array}{c}-0.0212^{* *} \\
(0.0107)\end{array}$ & & \\
\hline $\operatorname{VAN}^{2}$ & & & $\begin{array}{c}0.0009 * * * \\
(0.0002)\end{array}$ & $\begin{array}{c}0.0007 * * \\
(0.0002)\end{array}$ & & \\
\hline PR & & & & & $\begin{array}{c}-0.330^{* * * *} \\
(0.1172)\end{array}$ & $\begin{array}{c}-0.305 * * * \\
(0.1154)\end{array}$ \\
\hline $\mathrm{PR}^{2}$ & & & & & $\begin{array}{c}0.0369 * * \\
(0.0141)\end{array}$ & $\begin{array}{c}0.0344 * * \\
(0.0138)\end{array}$ \\
\hline AGEDEM & $\begin{array}{c}0.0038 * * \\
(0.0018)\end{array}$ & & $\begin{array}{c}0.0057 * * * \\
(0.0016)\end{array}$ & & $\begin{array}{c}0.0045^{* *} \\
(0.0019)\end{array}$ & \\
\hline DEMYEARS & & $\begin{array}{c}0.0047 * * * \\
(0.0016)\end{array}$ & & $\begin{array}{c}0.0055^{* * * *} \\
(0.0016)\end{array}$ & & $\begin{array}{c}0.0052^{* * *} \\
(0.0017)\end{array}$ \\
\hline $\log G D P$ & $\begin{array}{c}0.2967 * * * \\
(0.0411)\end{array}$ & $\begin{array}{c}0.2847 * * * \\
(0.0408)\end{array}$ & $\begin{array}{c}0.2913 * * * \\
(0.0417)\end{array}$ & $\begin{array}{c}0.2924 * * * \\
(0.0415)\end{array}$ & $\begin{array}{c}0.3192 * * * * \\
(0.0403)\end{array}$ & $\begin{array}{r}0.3044 * * * \\
(0.0401)\end{array}$ \\
\hline ECON_FREE & $\begin{array}{c}0.1842 * * * * \\
(0.0633)\end{array}$ & $\begin{array}{c}0.1807 * * * \\
(0.0620)\end{array}$ & $\begin{array}{c}0.2384 * * * \\
(0.00671)\end{array}$ & $\begin{array}{c}0.2388 * * * \\
(0.0671)\end{array}$ & $\begin{array}{c}0.1920 * * * \\
(0.0665)\end{array}$ & $\begin{array}{r}0.1874 * * * \\
(0.0652)\end{array}$ \\
\hline IMPORTS & $\begin{array}{c}0.0015 \\
(0.0021)\end{array}$ & $\begin{array}{c}0.0016 \\
(0.0019)\end{array}$ & $\begin{array}{c}0.0016 \\
(0.0021)\end{array}$ & $\begin{array}{c}0.0013 \\
(0.0021)\end{array}$ & $\begin{array}{c}0.0013 \\
(0.0021)\end{array}$ & $\begin{array}{c}0.0012 \\
(0.0020)\end{array}$ \\
\hline FED & $\begin{array}{c}0.0202 \\
(0.0972)\end{array}$ & $\begin{array}{c}0.0243 \\
(0.0951)\end{array}$ & $\begin{array}{c}0.0255 \\
(0.0974)\end{array}$ & $\begin{array}{c}0.0233 \\
(0.0964)\end{array}$ & $\begin{array}{c}0.0337 \\
(0.0955)\end{array}$ & $\begin{array}{c}0.0374 \\
(0.0934)\end{array}$ \\
\hline PROTESTANT & $\begin{array}{c}0.1958 * * \\
(0.0957)\end{array}$ & $\begin{array}{c}0.1881 * * \\
(0.0941)\end{array}$ & $\begin{array}{c}0.1276 \\
(0.0978)\end{array}$ & $\begin{array}{c}0.1416 \\
(0.0964)\end{array}$ & $\begin{array}{l}0.1667^{*} \\
(0.0977)\end{array}$ & $\begin{array}{l}0.1610^{*} \\
(0.0948)\end{array}$ \\
\hline BRITCOL & $\begin{array}{c}0.0937 \\
(0.0978)\end{array}$ & $\begin{array}{c}0.0953 \\
(0.0937)\end{array}$ & $\begin{array}{c}0.0562 \\
(0.0921)\end{array}$ & $\begin{array}{c}0.0692 \\
(0.0899)\end{array}$ & $\begin{array}{c}0.0937 \\
(0.0908)\end{array}$ & $\begin{array}{c}0.1044 \\
(0.0886)\end{array}$ \\
\hline Costant & $\begin{array}{c}-3.9005 * * * \\
(0.3450)\end{array}$ & $\begin{array}{c}-3.8064 * * * \\
(0.3432)\end{array}$ & $\begin{array}{c}-3.9098 * * * \\
(0.3476)\end{array}$ & $\begin{array}{c}-3.9371 * * * \\
(0.3435)\end{array}$ & $\begin{array}{l}-3.3277 \\
(0.4865)\end{array}$ & $\begin{array}{c}-3.277 * * * \\
(0.4892)\end{array}$ \\
\hline $\mathrm{R}^{2}$ & 0.8499 & 0.8553 & 0.8494 & 0.8501 & 0.8433 & 0.8493 \\
\hline AIC & 130.18 & 126.06 & 129.54 & 129.04 & 134.98 & 130.58 \\
\hline $\mathrm{N}$ & 112 & 112 & 111 & 111 & 112 & 112 \\
\hline
\end{tabular}

* Significant at 0.1

** Significant at 0.05 level.

*** Significant at 0.01 level. 
Figure 1. Distribution of sample countries according to their level of democracy (Polity score) and their degree of corruption control (CC) in 2000.

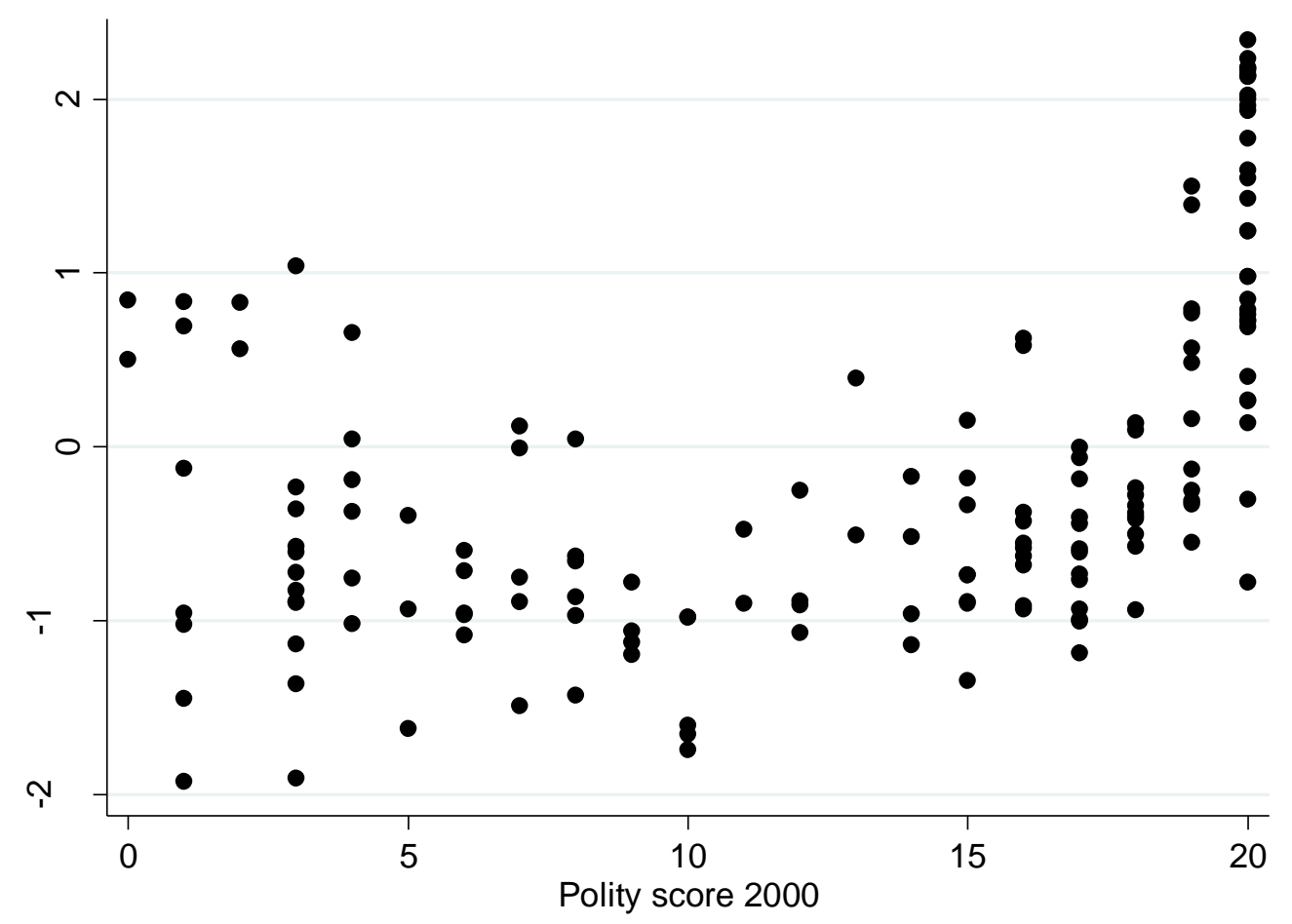

